\title{
RELIGIOUS SPLINTER MOVEMENT FROM HISTORICAL PERSPECTIVE
}

\author{
By: Hermanu Joebagio*
}

\begin{abstract}
This article tries to analyze splinter groups of Islamic religion in Indonesia. Islamization in Indonesia has been building in the framework of universal values that containes democracy, i.e. hifdz-din, hifdz-nafs, hifdz-nasl, hifdz-mal, and hifdz-aql. Political change occurred in 1998 had triggered the emergence of splinters of Islamic religion; they were Salamullah, Isa Bugis, Baha'i, Madi in Palu, Qur'an Suci, and al-Qiyadah al-Islamiyah. They used atmosphere of pluralism and inclusivism to form their splinters' community of religion. But, Ahmadiyah in historical perspective is different, because Ahmadiyah had existed before Indonesian Independence, and took part in resisting against Western colonization. The believe code of splinters of Islamic religion are deviant. They do not accepted Muhammad as the last prophet, change 'shahadat' and 'shalat'. However, some people do not agree to punish or accuse them as being "sesat (deviant)", because there still some chances to conversion.
\end{abstract}

tựáth

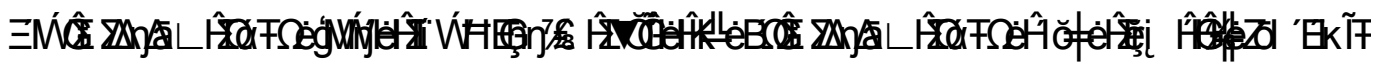

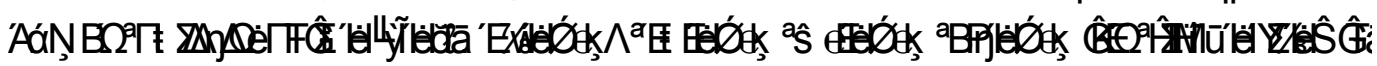

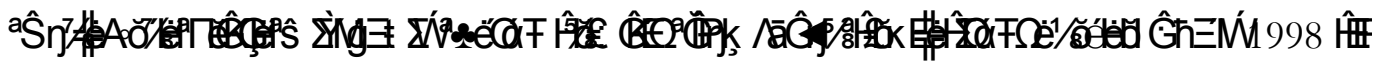

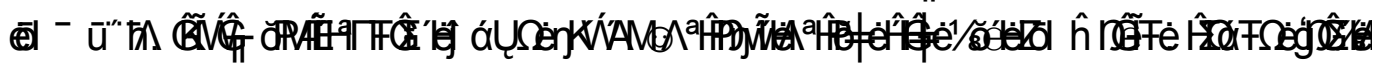

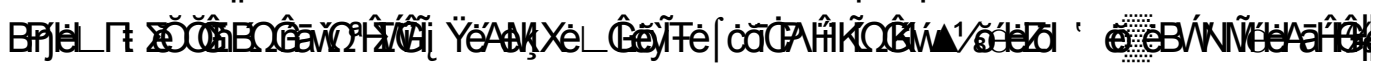

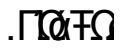

Keywords: Islam, doctrine, democracy, splinter group or movement, and violence.

\section{A. Introduction}

Religious splinter movements, which have been coming to appear lately, are a result of life crisis whether in the dimension of economy, politic or social. This crisis influences spiritual dimension of any individuals as well as groups, and even, they begin to look into "new" spirituality that they perceive of having wisdom. Such spirituality is conceived as really the truth so that when some people pose question on it along with fatwa from religious institution simply tensions is going to arise and trap them into violence.

Tensions need not to happen if understanding of religiosity takes place on the perspective of perennial philosophy. With this philosophy, it can be 
understood complexities of religion which should be accepted as relative, limited, partial and not comprehensive. ${ }^{1}$ It means religion has form as well as substance. When the substance of religion presents into our life, it comes with bordered form so that religion is at once universal and particular. For this, the form is relative although content of the substance is absolute. Bearing on perennial philosophy for understanding religion, particularly Islam, is an attempt of keeping off narrow outlook while at the same time opening new horizon, that religion will remain on its role as to liberate people.

Picture of splinter groups, in historical perspective, can be traced back to the $16^{\text {th }}$-the $19^{\text {th }}$ centuries. This picture does not doctrinal in nature but political, because bureaucracy which had been established really made distinction between those ulama of the noble class and those of ordinary ulama. ${ }^{2}$ The ordinary ulama had been marginalized politically through power of the ruling. It is this factor that makes the picture of splinter groups different between those in colonial era and those in reformation era. Splinter groups of the current (such as Ahmadiyah, who performs shalat using two languages in Malang, the sect of Madi in Palu, the community of Eden, al-Qiyadah al-Islamiyah, and the like) deny the Prophet Muhammad and change shahadat (the profession of faith in Islam) or the pattern of prayer (salat). This introductory study discusses why and how does it happen, namely the religious rebellion, seen from the perspective of historical politic and perennial.

\section{B. Splinter Movements: Between Sect and Opposition Typology}

1 Budhy Munawar-Rachman, Islam Pluralis: Wacana Kesetaraan Kaum Beriman, (Pluralist Islam: Discourse of Equality of Faith Community), (Jakarta: Raja Grafindo Persada, 2004), p. 101-109. Taking a brief look at religion (of Islam) perennially shows that it comes from the spout of "The Absolute". Like water, the substance is one, but it appears in many different forms as ocean, steam, cloud, rain, river, pool, dew and the like. See Sufyanto, "Pengantar: Agama Tuhan dan Problem Kemanusiaan”, (Preface: Religion, God and Problem of Mankind) in Pradana Boy ZTF (ed.), Agama Empiris: Agama dalam Pergumulan Realitas Sosial (Empirical Religion: Religion in Social Realities Encounter), (Yogyakarta: Pustaka Pelajar \& LP2IF, 2002), p. v-vi.

${ }^{2}$ Fachry Ali, "Masa Tak Berwarga Negara: Gerakan-gerakan Protes di Jawa Abad ke19”, (Mass Having not Nationality: Protest Movements in $19^{\text {th }}$ Century Java), in Asep Gunawan (ed.), Artikulasi Islam Kultural: Dari Tahapan Moral ke Periode Sejarah, (Articulation of Cultural Islam: From the Moral Stage to the Historical Period), (Jakarta: Raja Grafindo Persada, 2004), p. 247. 
Religious rebellion movement in the colonial period was not to change the doctrine of Islam, but more contended with having disloyalty in nature and disoriented of ulama to the political system as did take place in Mataram kingdom. Although at the time the system established by Sultan Agung did place Islam as source of social force that was having interrelationship with the world of politics, in reality Islam was simply instrumental to obtain political legitimation from ulama circles along with their mass basis. On the other side, Islam was used as political tool to establish absolute and centralistic power ${ }^{3}$. The use of Islam as a tool of politic was meant to put a basic ground of harmony between Javanese Culture and Islam. This discourse tends to be political, for there was Sultan Agung's desire of putting the palace forward as an agent of Islamization and of placing Islam a plate for reconciliation of the Javanese culture. ${ }^{4}$ Implication of this discourse in the context of political building was: (1) Islam constituted political instrument to solve social-culture problem, social-economy and socialpolitic faced by Sultan Agung, and also a tool to reach larger mass for building political power ${ }^{5}$ (2) Islam being adhered is mystical in character or syncretism, so that the ground for Islamization is to use that character of which is interpreted as in accord with the lower social classes and constitutes the essence of their culture. $^{6}$

To make sure that his power working well, Sultan Agung arranged the politic of "tanah perdikan" (the soil of perdikan) to Ulama of Mataram which contains double meanings; as a policy of containment and the tool of peaceful on one hand and as to put into practice manungaling kawula-gusti (the unity between

\footnotetext{
${ }^{3}$ Karkono K. Partokusumo, “Konsep Kekuasaan dan Pengembangan Kepemimpinan dalam Budaya Jawa” (the Concept of Power and Growing up Leadership within Javanese Culture), Prospektif, No. 1, Vol. 4, 1992, hal. 87-88.

${ }^{4}$ Merle C. Ricklefs, "Islamising Java: The Long Shadow of Sultan Agung”, in Archipel, Vol. I, No. 56, 1998a, p. 469-482.

${ }^{5}$ M.C. Ricklefs, The Seen and Unseen Worlds in Java 1726-1749: History, Literature and Islam in the Court of Pakubuwana II, (Honolulu: Allen \& Unwin and University of Hawai'i Press, 1998b), p. xvii-xix; See also Azyumardi Azra, "Islam dan Negara: Eksperimen dalam Masa Modern, Tinjauan Sosio-Historis”, (Islam and the State: An Experiment in Modern Era), in Asep Gunawan (ed.), Op. Cit., p. 142-143.

${ }^{6}$ Niels Mulder, Individual and Society in Java: A Cultural Analysis, (Yogyakarta: Gadjah Mada University Press, 1992), p. 4-19.
} 
the creature and the Creator) as the power of God (Ilahiah) ${ }^{7}$. The power of Ilahiah which is sticky in the manunggaling kawula-gusti constitutes a symbol that the king does not have to be responsible for the policy he has made, while the governed people simply has to affirm whatever the king wanted. Such power of magic-religious symbolizes the fate of people which is fully dependent on the king's vision. A king with good vision will take any efforts to build prosperous life, and on the contrary a careless king of course will only cause poverty. ${ }^{8}$

The Manunggaling kawula-gusti is a discourse of spiritual curiosity of religion through mystic. This phenomenon is acknowledged within the philosophy of perennial. When life experienced a kind of upheaval, because of structural changes whether in economy or in politic which stressed the life of individual, practices of religion is influenced in term of Shari'ah. This upheaval then needs to be balanced by tracing the way of religion through mystic ${ }^{9}$. In their view, the way of mystic is a realistic way to avoid physiological stresses, because this way habituates the power of spiritual (mujahadah), spiritual sight (musyahadah) and empathy. ${ }^{10}$ The top of this way of mystic is ability to face the God. Experience to be together with the God is well known as wahdat al-wujud. ${ }^{11}$

The very personal nature of religious experience above then spread out to build a community, namely the sect of tarekat. This sect was seen by elite politicians of Mataram as the sect of splinter. On the other hand, Babad and Serat written by kings and men of letter of Mataram Era shows the faith of Mataram elites that still believe in Allah, al-Qur'an, syahadat, shalat and there was no

${ }^{7}$ Karel A. Steenbrink, Beberapa Aspek tentang Islam di Indonesia Abad ke-19 (Some aspects of Islam in the $19^{\text {th }}$ Century of Indonesia), (Jakarta: Bulan Bintang, 1984), p. 30; See also Simuh, Mistik Islam Kejawen Raden Ngabehi Ranggawarsita: Suatu Studi terhadap Serat Wirid Hidayat Jati (Mystic of Islam and Kejawen of Raden Ngabehi Ranggawarsita: A Study of te Serat Wirid Hidayat Jati), (Jakarta: University of Indonesia Press, 1988), p. 27-29.

${ }^{8}$ Soemarsaid Moertono, "State and Statecraft in Old Java: A Study of the Later Mataram Period, $16^{\text {th }}$ to $19^{\text {th }}$ Century”, a.b. YOI, Negara dan Usaha Bina Negara: Studi tentang Mataram II, Abad XVI Sampai XIX, (The State and Effort of Building State: The Study of Mataram II, XVI to XIX Centuries), (Jakarta: YOI, 1985), p. 17-96.

${ }^{9}$ Azyumardi Azra, Historiografi Islam Kontemporer: Wacana, Aktualitas, dan Aktor Sejarah (Contemporary Islamic Historiography: Discourse, Actuality and Historical, (Jakarta: Gramedia Pustaka Utama, 2002), p. 202.

${ }^{10}$ Budhy Munawar-Rachman, Op. Cit., 248.

${ }^{11}$ Ibid., p. 119-120. 
intention to change these believes. Although elites of Mataram believe in Islamic doctrine, Shari'ah was relatively nominal. According to Martin van Bruinessen, ${ }^{12}$ the reasons of tarekat groups became opposition were: (1) basis of mass of this groups is large, spread in all region; (2) they have networks of communication in social and politic between different groups; (3) political repression to the people through the forced and private plantation; (4) the King was neglectful of rising the prosperity of people; (5) political repression and marginalization of ordinary ulama.

The tendency of politician elites of Mataram to perceive the way of religion on political bases has caused accusations such as "fundamentalism" and "subversive” to appear. Such accusation has given rise phobia among religious communities, as this model had been practiced during the era of colonialism and during the reign of New Order to face groups and movements which were the opposite ideology and interest of the ruling government. The political cases of Syekh Siti Jenar, Syekh Amongrogo, Ki Bebeluk, KH. Ahmad Mutamakin, and many others markedly assigned encounters between traditional Javanese mysticism and orthodox legalistic Islam. ${ }^{13}$ Morover, appointment of many ordinary ulamas as the King personal advisers (Paku Buwana IV) ${ }^{14}$, with equal

\footnotetext{
${ }^{12}$ Martin van Bruinessen, “Tarekat dan Politik: Amalan untuk Dunia atau Akherat?”, (Tarekat and Politic: Religious Practices for Worldly Purposes or the hereafter?) in Pesantren, No. 1, Vol. IX, 1992, p. 9-13.

${ }^{13}$ Since the beginning of the spread of Islam in Java, there has been conflict between traditional Javanese mysticism (the Mystic of Java) and orthodox legalistic Islam (Pure Islam). Conflict, in one hand, shows the power of Islam as the rahmatan lil alamin, (blessing for the universe); that although different in 'sect' still one is considered as being a true Muslim. However, in other hand, it results negatively for often to be said tha Islamization in Indonesia has not yet been fully comprehensive. See S. Soebardi, "Santri-religious Elements as Reflected in the Book of Tjentini”, in Bijdragen tot de Taal-, Land-en Volkenkunde (BKI), No. 127, 1971, p. 331-349.

${ }^{14}$ Since young PB IV has been making good relationship with ulamas around Surakarta, and it makes him easier to build political ties when he became Sunan. PB IV had been with Kyai Imam Syuhada (1745-1843) from Pesantren Wanareja, Bekonang for learning religion. Imam Syuhada is a son of Kyai Trunasura, Bagelen, and grandchild of Kyai Ageng Baidlowi, Purwareja. Imam Syuhada earns his religious education from his parents and from the pesantren of his grand father in Purwareja. Imam Syuhada then searching for knowledge in Pesantren of Jatisaba, under the supervisory of Kyai Khotib Iman. The chief of this pesantren was also abdi dalem ulama (the ulama of the palace Kasunanan) which was in charge to become Khatib (lecturer in Friday prayer) of the mosque of the biggest (Masjid Agung). When Imam Syuhada was ordered to build pesantren in Wanareja, he got support from PB IV, included ompak (the resting pole), soko (pole), mustaka (head), (podium) mimbar, and the control lamp. See Supariadi, Kyai dan Priyayi di Masa Transisi, (kyai and priyayi in Transition period), (Surakarta: Pustaka Cakra, 2001), p. 146-159.
} 
position as pepatih dalem (high positions palace), has caused political fluctuation which almost disrupted the palace of Kasunanan. ${ }^{15}$

The principle of manunggaling kawula-gusti converted to the area of politic was an attempt to establish political unity at that time that the ruling can operate the function of control mechanism for establishing political stability and security. ${ }^{16}$ However, such practice of politic as that in fact just grew up a centralistic absolute power and also became the reason for defending status quo.

On the other side, Islamic ideology holds on the principle of egalitarianism which is presented in the life of universalism, contains of values as hifdz-din (the right to have free religious profession), hifdz-nafs (the right of live), hifdz-nasl (right of having descendants), hifdz-mal (right of having properties), hifdz-aql (right to have creative and of having opinion) ${ }^{17}$. All are the values which esteem highly the democracy of religion, of the state and nation.

The above values of universalism shows that Islam in terms of normativedoctrinal does not shackle creativities of its adherents in developing doctrine and religious teaching as long as not contradicts with the basic principle. This, however, fully dependent on how far the quality of reasoning of Muslim intellectuals is. Accuses that Syekh Siti Jenar, Syekh Amongrogo, Ki Bebeluk, KH. Ahmad Mutamakin, and many others had taught the deviated sect to society, and caused worries among people are of political nuance. More importantly this phenomenon was not in the context of the typology of sect or group of splinter. It was the basis of mass of such religious men elites actually that worried politician elites. Their political pressure to the communities of religion had forced the latter

\footnotetext{
${ }^{15}$ The palace of Kasunanan was encircled from three directions: from the south, by the troops of Hamengkubuwana I; from the north, by the troops of Mangkunegara I; and from the west by the troops of the Netherlands. The demands were to persecute to dead ulamas of personal advisor PB IV. Those ulamas were Kiai Bahman, Kiai Nursaleh, Kiai R. Santri, Kiai Wiradigda, Kiai Panengah, Kandhuruan, Wirareja, and Sujanapura. See Yasadipura I, "Babad Pakepung”, transliterasi \& a.b. Endang Saparinah, Babad Pakepung, (Surakarta: Fakultas Sastra UNS, 1989), p. 24-37.

${ }^{16}$ Ong Hok Ham, “Kepemimpinan dalam Sejarah Indonesia” (Leadership in the History of Indonesia), Prisma, No. 6, Tahun XI, June 1982, p. 6.

${ }^{17}$ Moch. Musoffa Ihsan, "Nilai-Nilai Islam dan Modernitas" (Islamic Values and Moderrnity), Kompas, Wednesday, $5^{\text {th }}$ November 2003, p. 43; See also Aden Wijdan SZ (et. al.), 2007, Pemikiran dan Peradaban Islam (Thoughts and Civilization of Islam), (Yogyakarta: Safiria Insania Press, 2003), p. 205-207.
} 
to put them as being an opposition. If religious thought at that time, namely the focus of orthodoxy (religious teachings of the ruling claimed as the truth), was moved to that of orthopraxis (religious teachings focus on the practical realities) in establishing the above Islamic universalism values it may violence as well repressing action to communities of society may had been decreased ${ }^{18}$. By moving to orthopraxis, it may certain that the life of harmony between the different communities of faiths as well as between the same faiths of religious communities will be in reality today within a plate of a nation ${ }^{19}$

\section{The Antagonistic Past}

The reign of the Old Order (Soekarno) and the New Order (Soeharto) showed off the practice of gruff attitude to the ideology of Islam, particularly if its adherent had been in opposition to the government political mainstream. This style of politic had been basically similar to the policy of Islam of Snouck Hurgronje. $^{20}$ These styles of politic really caused the political creativities of Muslims barren, even there was political pressure along with some policies which perceived by Muslim as a process of “Christianization” . According to Martin van Bruinessen, internal as well as global pressures to Islamic ummah give rise to the appearance of the Islamic Board of Dakwah Indonesia (DDII) in 1967 and the Committee of Solidarity for the World of Islam (KISDI) which was established by the DDII activist in $1990 .^{21}$ Furthermore he says:

Kristenisasi, Christianization, through the spread of Christian institutions and proselytization among Muslims, was a key element in this perceived strategy. Another aspect was the forced depoliticization of Islam and de-Islamization of the state apparatus in the early New Order, a policy widely attributed to Ali Murtopo and the Chinese Catholic intellectuals manning the influential think tank CSIS. Apprehension about Kristenisasi were strongest among the activists of

\footnotetext{
${ }^{18}$ Trisno S. Susanto, "Membaca (Kembali) Politik Pluralisme” (Re-Reading of the Politic of Pluralism), Kompas, Saturday, $1^{\text {st }}$ April 2006, p. 39.

${ }^{19}$ Ibid.

${ }^{20}$ Bachtiar Effendy, Masyarakat Agama dan Pluralime Keagamaan (Society, Religion and Religious Plurality), (Yogyakarta: Galang Press, 2001), p. 54-66.

${ }^{21}$ Martin van Bruinessen, "Post-Soeharto Muslim Engagements with Civil Society and Democratization”, in Hanneman Samuel \& Henk Schulte Nordholt (ed.), Indonesia in Transition: Rethinking 'Civil Society', 'Region', and 'Crisis', (Yogyakarta: Pustaka Pelajar, 2004), p. 40.
} 
the Indonesian Council for Islamic Predication (DDII), a body that had been established in 1967 by Muhammad Natsir and other former leaders of the Masyumi party. Kristenisasi in global term, as part of a wider Jewish-Christian conspiracy against Islam. They became increasingly interest in the confrontations between Muslims and superior enemies that appeared to be taking place across the globe.... ${ }^{22}$

Implication of the above political style of Soekarno and Soeharto was the disappearance of the typology sect or the splinter movements. What came to appear then was the encounter between Islamic ideology and global power. According to Agus Muhammad, ${ }^{23}$ to destroy Islam in order not to be threatening the consolidation of the Order it was conducted with in three ways, namely: (1) destroying Islamic groups as political force which is against the ruling, by way of repression or to stigmatize 'Islam' as an ideology to change Pancasila; (2) making political parties free from religious elements, this was carried out by the policy of the sole basis of Pancasila (Asas tunggal Pancasila); (3) embracing moderate groups of Islam to give their endorsement to the political structure of the New Order. This was marked by the ICMI. Such efforts of making of Islam benign had done by the regime have caused radical groups of Islam to metamorphose. They moved under ground, particularly in universities by spreading a literal understanding that only Islam is the solution to the crisis of the country. ${ }^{24}$

When Soeharto collapsed, and the corridor of democracy opened with the consciousness of developing plural society, there came into being three religious groups, namely (1) the typology of moderate; (2) the literal with fundamentalist nuance, that is the will of forcing Islamic shari'ah law, and (3) the splinter sect. The typology of splinter is obvious within the sects of Ahmadiyah, Salamullah, Isa Bugis, Baha'i, shalat dua rakaat di Jatim, Madi di Palu, al-Qur'an Suci, dan alQiyadah al-Islamiyah, whereas the typology of literal or fundamentalist are those groups who are against the global capitalist power.

In political perspective, the appearance of such splinter sects is to take advantage of state political changes which is opening the corridor of democracy

\footnotetext{
${ }^{22}$ Ibid., p. 39-40.

${ }^{23}$ Agus Muhammad, "Islam, Radikalisme, dan Politik Global” (Islam, Radicalism and Global Politic), Kompas, Saturday, $1^{\text {st }}$ April 2006, p. 38.

${ }^{24}$ Ibid.
} 
and plural life as it has been suggested by leaders of reformation such as Nurcholish Madjid, Abdurrahman Wahid, and Amien Rais. However, Ahmadiyah's perspective is different with other splinter groups. The Amadiyah of Lahore was established in Indonesia by R.Ng. H. Mihadjurrahman Djojosugito, in tahun $1928 .^{25}$ The objective of this establishment is to fight against Christian countries repressive and hostile to Muslims. ${ }^{26}$ Although the doctrine and the teaching of Ahmadiyah violates the basic principle of Islam, their existence, however, has not yet caused violence in social life. It was the nuance of the Western colonialism that supported Ahmadiyah, even, it has been spread out in countries all over the world, namely in Asia, Africa, Europe, Australia, and America. $^{27}$

The era of reformation opened the chance for any groups of religion to carry out political as well as religious movements. In such situation, groups of religion or religious study groups were urged to conduct gatherings internally as well as with other different groups of religious understanding along with their masses. This tendency on one hand is really supporting the plurality. However, in other hand this also makes sure that deviation from the mainstream is happening. ${ }^{28}$ There are two aspects indicated to cause the awakening, namely: (1) splinter movements take advantage of the state political changes, (2) there some established political power that wants to establish political ife mre "plural", and this increasingly open the chance to the awakening of splinter movements.

Phenomena that are observable in this era of reformation are that splinter movements chose to free themselves off from politics compared with those of religious fundamentalism groups. This sort of leaving off the politic is actually their intention not to disturb the politic of government, and at the same time they are perceive to be a form of plurality in response to the issues of militant-ism

${ }^{25}$ H. Aboebakar, Sedjarah Hidup KH. A. Wahid Hasjim dan Karangan Tersiar Life History of KH. A. Wahid Hasjim and his Published Works), (Djakarta: Panitya Buku Peringatan Alm. KH. A. Wahid Hasjim, 1957), p. 127.

${ }^{26}$ Ibid., p. 128-132.

${ }^{27}$ Ibid., p. $129-131$.

${ }^{28}$ Komaruddin Hidayat, "Mengadili Keyakinan Agama” (Blamming the Believe of Religion), Kompas, Tuesday, $3^{\text {rd }}$ Januari 2006, p. 7. 
often voiced by global power. ${ }^{29}$ However, groups of the literal typology are very much against the existence of splinter sects and movement, because they disagree with the doctrine, such as: not acknowledges Muhammad as the last prophet; changes the form of shahadat and reduce the amount of rakaat of shalat. It not surprising that literal group labeled the splinters as “deviation”.

However, it is naïve that the giving the symbol of "deviant" changes to the symbol of violence. Burning of houses of religious, destroying houses and torture to its adherent are forms of violence, which is perennially can or according to right of human being not be legitimized, since the splinters are still believing in “The Lord” and “The” One. ${ }^{30}$ In this context, Komaruddin Hidayat says:

Pertaining to faith....which rooted in the heart and thought which shaped by learning and life experiences it is really not easy to be subjected and being judged. However, it does not mean... that their believes can not be converted...movement such as Ahmadiyah and Lia Aminuddin and the like are judged of being deviate the understanding and the believes of the majority which have been honored and preserved...But to trap with the reason of disturbance....is problematic because its subjectivity. ${ }^{31}$

In fact, the doctrines believed by adherents of splinter movements are still likely to be converted into (Islamic) understanding of mainstream. Problems faced by such adherent among other things are limitation in understanding the “meaning”, thereby they are of easily misunderstood by vocabularies of religious language without taking consideration of sociological reality. Formulations of religious language than are abused by leader of splinter groups, even to force the practice of day to day religious life so that such formulation of religious language faces social realities controversies appeared in turn. This problem of understanding of religious text is often to appear that caused divided opinions in Islam. Based on this, many adherents of splinter groups are actually trapped between extremely contradictive poles, between commitment to direct contact with God, the authority of mainstream, and appearance of individual interest as

\footnotetext{
${ }^{29}$ Khaled M. Abou El Fadl, The Great Theft: Wrestling Islam from the Extremists, (New York: HarperCollins, 2005), p. 1-7, 11-25.

${ }^{30}$ Budhy Munawar-Rachman, Op. Cit., p. 103-105.

${ }^{31}$ Komaruddin Hidayat, Op. Cit.
} 
that of splinter groups leaders. The appearance of such leaders are misinterpreted as a great organization, because the more fatwa be given and accused them as “deviant” the more such splinter groups come to appear.

Adherents of splinters groups perceived as being deviant become the accused people, they are judged by masses. May be such a fatwa does not take the change to convert to mainstream as consideration. As a result, adherents of splinters groups are marginalized socially. They become the others (those who do not have the same understanding and ideology) which in reality is symbolized by infidel, hypocrite, apostate, deviants, dajjal the enemy of Islam and candidate of hell. $^{32}$ To convert those of slinter groups's adherent into the mainstream is easy, but it takes time and process. In Robert N. Bellah thought, adherents of splinters have string their selves to God, and this is an enduring power that constitutes their guidance. $^{33}$

Their limitation to understand "meaning" of formulation of religious language has not yet been the basis for the big other (the mainstream of religious understanding) to reproduce self-image of splinter movement adherent toward the ideal image wanted by the mainstream. ${ }^{34}$ If this assumption is agreed, the mainstream has to open the horizon of nahdhah (awaken). Nahdah is originally taken from the word nahd, mean "to stand up or to get up from the seat". ${ }^{35}$ The big other, has to be able to move the others to something new and right, along with efforts and agreements as a project of rehabilitation and empowerment, ${ }^{36}$ and this project is called self-image reproduction. The ability of the big other to reproduce self image of splinter adherents is identical with the ability to vanish the wall of exclusivism and to put awakening (nahdah) to face the new millennium challenges. The ability of the big other to establish self image will present

\footnotetext{
${ }^{32}$ Abdul Munir Mulkhan, "The Others dalam Sistem Keberagamaan” (The Others within Religious System), Kompas, Friday, $25^{\text {th }}$ November 2005, p. 6.

${ }^{33}$ Robert N. Bellah, "Beyond Belief: Essays on Religion in Post-Traditionalist World", a.b. Rudy Harisyah Alam, Beyond Belief: Menemukan Kembali Agama, (Jakarta: Paramadina, 2000), p. 209.

${ }^{34}$ Ahmad Baso, Islam Pasca Kolonial: Perselingkuhan Agama, Kolonialisme, dan Liberalisme Post Colonialism Islam: Religion, Colonialism and Liberalism), (Bandung: Mizan, 2005), p. 65-79.

${ }^{35}$ Ibid., p. 92.

${ }^{36}$ Ibid., p. 89-99.
} 
symbols and values that it's nuance will also present in every places, influences and forms the structure of culture, economy, politic and social. In such condition, it is hoped to appear the life that respect ortoprax and not being rigid to the formula of religious language, so that the step of self image or nahdah can be use to solve religious problems nowadays.

\section{Conclusion}

The appearance of splinter sects or movement lately, seen from historical perspective, is not a new phenomenon. Thought of splinter sect or movement in the past was bias, and from one time to another its nuance has been in line with political tendencies. In colonial era, appeared encounter between traditional Javanese mysticism and orthodox legalistic Islam. This encounter seems to be designed by the colonial to reduce the power of Islam. During the period of independency until the New Order, the sects of splinter had not attracted public attention, because they had not been in opposition to the government political mainstream, even the nuance of mystic was legalized by the government by recognizing the "aliran kepercayaan" (the sect of (Javanese) faith). In the era of reformation, splinter movements is dare to appear to the surface as a part of reformation euphoria, even outspokenly declared in opposition to the doctrine of Islam. The fatwa of being "deviate" given by some religious leaders has put them as the accused and made them being marginalized socially, whereas they still can be converted to the understanding of Islamic mainstream. 


\section{BIBLIOGRAPHY}

H. Aboebakar. 1957. Sedjarah Hidup KH. A. Wahid Hasjim dan Karangan Tersiar, Djakarta: Panitya Buku Peringatan Alm. KH. A. Wahid Hasjim.

Azyumardi Azra. 2002. Historiografi Islam Kontemporer: Wacana, Aktualitas, dan Aktor Sejarah. Jakarta: Gramedia Pustaka Utama.

Ahmad Baso. 2005, Islam Pasca Kolonial: Perselingkuhan Agama, Kolonialisme, dan Liberalisme. Bandung: Mizan.

Bellah, Robert N.. 2000. "Beyond Belief: Essays on Religion in PostTraditionalist World”, a.b. Rudy Harisyah Alam, Beyond Belief: Menemukan Kembali Agama, .Jakarta: Paramadina.

Bruinessen, Martin van. 1992. "Tarekat dan Politik: Amalan untuk Dunia atau Akherat?”, Pesantren, No. 1, Vol. IX, 1992.

Bachtiar Effendy. 2001, Masyarakat Agama dan Pluralime Keagamaan. Yogyakarta: Galang Press.

Khaled M. Abou El Fadl. 2005. The Great Theft: Wrestling Islam from the Extremists. New York: HarperCollins.

Asep Gunawan (ed.), Artikulasi Islam Kultural: Dari Tahapan Moral ke Periode Sejarah, Jakarta: Raja Grafindo Persada.

Ong Hok Ham. 1982. "Kepemimpinan dalam Sejarah Indonesia”, Prisma, No. 6, Tahun XI, June 1982.

Komaruddin Hidayat. 2006. "Mengadili Keyakinan Agama”, in Kompas, 3 January.

Moch. Musoffa Ihsan. 2003. "Nilai-Nilai Islam dan Modernitas”, in Kompas, 5 November.

Soemarsaid Moertono. 1985. "State and Statecraft in Old Java: A Study of the Later Mataram Period, $16^{\text {th }}$ to $19^{\text {th }}$ Century", a.b. YOI. Negara dan Usaha Bina Negara: Studi tentang Mataram II, Abad XVI Sampai XIX, Jakarta: YOI.

Agus Muhammad. 2006. “Islam, Radikalisme, dan Politik Global”, in Kompas, 1 April.

Mulder, Niels. 1992. Individual and Society in Java: A Cultural Analysis. Yogyakarta: Gadjah Mada University Press.

Abdul MunirMulkhan. 2005. "The Others dalam Sistem Keberagamaan”, in Kompas, 25 November.

Budhy Munawar-Rachman. 2004. Islam Pluralis: Wacana Kesetaraan Kaum Beriman. Jakarta: Raja Grafindo Persada. 
Karkono K. Partokusumo. 1992. "Konsep Kekuasaan dan Pengembangan Kepemimpinan dalam Budaya Jawa”, Prospektif, No. 1, Vol. 4.

Merle C. Ricklefs. 1998a. "Islamising Java: The Long Shadow of Sultan Agung”, Archipel, Vol. I, No. 5, 1998.

1998b. The Seen and Unseen Worlds in Java 1726-1749: History, Literature and Islam in the Court of Pakubuwana II, Honolulu: Allen \& Unwin, and University of Hawai'i Press.

Samuel, Hanneman \& Henk Schulte Nordholt (ed.), Indonesia in Transition: Rethinking 'Civil Society', 'Region', and 'Crisis'. Yogyakarta: Pustaka Pelajar.

Simuh.1988. Mistik Islam Kejawen Raden Ngabehi Ranggawarsita: Suatu Studi terhadap Serat Wirid Hidayat Jati, Jakarta: Universitas Indonesia Press.

Soebardi, S. 1971. "Santri-religious Elements as Reflected in the Book of Tjentini”, Bijdragen tot de Taal-, Land-en Volkenkunde (BKI), No. 127, 1971.

Steenbrink, Karel A.. 1984. Beberapa Aspek tentang Islam di Indonesia Abad ke19. Jakarta: Bulan Bintang.

Supariadi. 2001. Kyai dan Priyayi di Masa Transisi. Surakarta: Pustaka Cakra.

Susanto, Trisno S.. 2006. “Membaca (Kembali) Politik Pluralisme”, in Kompas, 1 April.

Aden Wijdan SZ. (et. al.). 2007. Pemikiran dan Peradaban Islam. Yogyakarta: Safiria Insania Press.

Yasadipura I, .1989. "Babad Pakepung”, transliterasi \& a.b. Endang Saparinah, Babad Pakepung, Surakarta: Fakultas Sastra UNS. 